\title{
Effect of Deltamethrin on the Leaf Miner (Liriomyza cicerina) of Chickpea and its Parasitoids
}

\begin{abstract}
Abir Soltani, Soumaya Haouel-Hamdi Laboratoire de Biotechnologie Appliquée à l'Agriculture, INRAT, Université de Carthage, Tunis, Tunisia, Moez Amri, International Center for Agricultural Research in the Dry Areas (ICARDA), Rabat, Morocco, and Jouda Mediouni-Ben Jemâa, Laboratoire de Biotechnologie Appliquée à l'Agriculture, INRAT, Université de Carthage, Tunis, Tunisia https://doi.org/10.52543/tipp.15.2.3

(Tunisia/Morocco)

ABSTRACT

Soltani, A., Haouel-Hamdi, S., Amri, M., Mediouni-Ben Jemâa, J. 2020. Effect of deltamethrin on the leaf miner (Liriomyza cicerina) of chickpea and its parasitoids. Tunisian Journal of Plant Protection 15 (2): 59-67.
\end{abstract}

The objective of this work was to investigate the effects of chemical treatments on larvae and adults of the chickpea leaf miner (Liriomyza cicerina) and its parasitoids. The study was conducted according to the split-plot design with three replicates, during the cropping seasons 2016 and 2017 in the northwestern Tunisia. Deltamethrin treatments were applied on winter and spring chickpea varieties (Nour and Amdoun, respectively) when the pest density reached a level of 2-3 larvae/leaf in 50\% of plants in the field. The number of emerged parasitoids and pest adults were recorded, and parasitism rates were investigated after treatments. Results revealed that the number of captured pest adults has been reduced in treated plots compared to control ones. Respective reduction rates attained $64.15 \%$ and $60.17 \%$ for Nour and Amdoun varieties during 2017. Additionally, the highest and the lowest parasitism rates were recorded respectively for Opius monilicornis $26.09 \%$ on control samples and for Diaulinopsis arenaria $2.88 \%$ on treated samples of Nour variety. In all experiments, L. cicerina larvae adults and parasitoids mortalities were higher for the spring variety. Hence, the use of more selective insecticides should be recommended to reduce the negative side-effects on the chickpea leafminer natural enemies.

Keywords: Chickpea, deltamethrin, Liriomyza cicerina, northwestern Tunisia, parasitoids

Chickpea agromizid leaf miner fly Liriomyza cicerina (Rondani 1875) (Diptera: Agromyzidae) is an economically important insect attacking legumes (El-Serwy 2003; Spencer 1976). It is one of the most dangerous pest

Corresponding author: Abir Soltani

Email: soltany.abyr@gmail.com

Accepted for publication 04 November 2020 affecting chickpea crops (Naresh and Malek 1986) and contributing in its yields' reduction (Soltani et al. 2020). This insect is well adapted to the climatic conditions of North Africa (Reed et al. 1987; Spencer 1976) and Asia (Cikman and Uygun 2003) where it causes heavy damage. The expansion of Liriomyza species has caused considerable damage to agro-ecosystems (Wan and Yang 2016). Cost-effective control strategies that may possibly limit the infestation rates caused by $L$. cicerina and enhance 
the yield are the way forward to manage the economic damage induced by this pest. Populations of L. cicerina are effectively controlled by its natural enemies (Del Canizo 1934), mainly the Braconidae Opius monilicornis (Soltani et al. 2018).

In order to ensure the food security and overcome the damage caused by this pest in the field, many measures should be undertaken as chemical and bio-technique methods (Çikman et al. 2008). Pesticides applications are the most widely used control methods against L. cicerina in the Integrated Pest Management program (Weigand and Lateef 1994) and are recommended because of their substantial role to reduce the leafminer infestation and increase chickpea yield (Weigand 1990), although these treatments have a negative sideeffect on leafminer parasitoids, and are considered unfriendly with the environment (El-Bouhssini et al. 2008).

In this context, the main objectives of the present study are (i) to determine the effect of deltamethrin treatments on leafminer larvae and adults of L. Cicerina in chickpea crops and (ii) to assess the side-effect of these treatments on L. cicerina parasitoids.

\section{MATERIALS AND METHODS Study site.}

The study was carried out during 2016 and 2017 in the experimental station of the Field Crops Regional Research Center (CRRGC) (Beja, 36 $6^{\circ} 44^{\prime} \mathrm{N}$, $\left.9^{\circ} 13^{\prime} \mathrm{E}\right)$ in Northwestern Tunisia, belonging to the sub-humid bioclimate. Chickpea was sown in December (winter chickpea crops, variety Nour, Pedigree: X96TH61-A3-W1-A2-W1- A1-W1-W1) and March (spring chickpea crops, variety Amdoun, Pedigree: Be-sel-81) in a splitplot design (lines $5 \mathrm{~m}$ long, spaced $0.5 \mathrm{~m}$ between the rows).

\section{Sampling.}

In order to find out the effectiveness of the chemical treatment, deltamethrin (Decis 50\% EC; Bayer Crop Science, France) was used at the dose of $1.5 \mathrm{ml} / \mathrm{hl}$ water, three times through the cropping season. From each variety, 30 leaves were sampled from the top, the middle and the base of 10 chickpea plants randomly chosen from each plot $\left(16.2 \mathrm{~m}^{2}\right)$ during different chickpea development stages. Untreated plots without chemical spraying served as a control.

\section{Treatment assessment.}

To assess the larvicidal impacts of deltamethrin treatments, dead larvae (blackened and immobile) and emerged adults from treated larvae were counted. Individual leaflets containing live larvae were placed in a transparent plastic boxes $(1600 \mathrm{ml})$ closed with cotton ball and covered with muslin at $25 \pm 2{ }^{\circ} \mathrm{C}, 70 \pm$ $5 \% \mathrm{RH}$ and 14:10 $\mathrm{h}$ (L:D) photoperiod until adult emergence of both the insect pest and its parasitoids. Larva mortality and adult emergence were compared to control samples. After emergence, both insect pest and parasitoids specimens were recorded, conserved in $70 \%$ ethanol and stored at $-4{ }^{\circ} \mathrm{C}$.

In the field, adults were monitored using yellow sticky traps set from sowing to pod setting stages and placed $10 \mathrm{~cm}$ above the top of the plant. The evolution of leafminer adult captures was recorded along the treatments. Reduction percentage of caught adults was assessed using the formula of Toker et al. (2010):

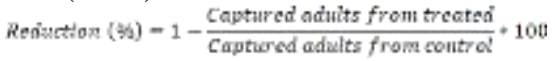

Emerged parasitoids from treated and control samples were daily counted, recorded and identified. The parasitism rate was determined following formula of Russel (1987): 


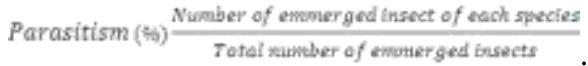

\section{Statistical analysis}

Statistical analyzes were performed using "SPSS statistical software version 20.0". Significant differences between the mean values $(P<$ 0.05 ) were determined by ANNOVA 1 factor followed by the Duncan multiple comparison test. The values presented were the mean of three replicates and were expressed as mean \pm standard error.

\section{RESULTS \\ Effects of chemical treatments on adult capture.}

Caught adults were lower for the winter variety (Nour) during the two seasons, with 44.89 adults/trap in 2016 and 47.9 adults/trap in 2017 compared to the spring variety (Amdoun), with 57.83 adults/trap in 2016 and 59.56 adults/trap in 2017 (Table 1). Statistical analyzes showed a high significant difference of captured adults among the two seasons $(\mathrm{df}=3, \mathrm{~F}=73.89, P<0.001)$ and between the two varieties $(\mathrm{df}=1, \mathrm{~F}=$ $10.58, P<0.001)$.

The chemical treatments were effective against $L$. cicerina adults. Statistical analyzes for Nour variety showed a high significant reduction for both seasons of each year [2016 $(\mathrm{df}=1, \mathrm{~F}$ $=77.7, P<0.001) ; 2017(\mathrm{df}=1, \mathrm{~F}=$ 90.4, $P<0.001)]$. Same results were obtained for Amdoun variety [2016 $(\mathrm{df}=$ $1, \mathrm{~F}=90.7, P<0.001) ; 2017(\mathrm{df}=1, \mathrm{~F}=$ 225.03, $P<0.001)]$. Besides, respective reduction ratesreached $64.15 \%$ and $60.17 \%$ for Nour and Amdoun varieties during 2017, respectively (Table 1).

Adult numbers vary according to the crop development stage. The lowest number of caught adults was recorded during the vegetative stage in the control plots, with 26 adults/trap and 28.6 adults/trap for Nour variety versus 37 adults/trap and 53.6 adults/trap for Amdoun variety respectively during 2016 and 2017. For treated plots, numbers of recorded adults were7 and 11 adults/trap for Nour, and 17 and 25.3 adults/trap for Amdoun respectively during 2016 and 2017.

Table 1. Effect of deltamethrin treatment on captured adults during 2016 and 2017

\begin{tabular}{l|cc|cc}
\hline \multirow{2}{*}{ Treatment } & \multicolumn{2}{|c|}{$\mathbf{2 0 1 6}$} & \multicolumn{2}{c}{$\mathbf{2 0 1 7}$} \\
\cline { 2 - 5 } & Nour & Amdoun & Nour & Amdoun \\
\hline Control & $44.89 \pm 2.9^{\mathrm{Ba}}$ & $57.83 \pm 2.7^{\mathrm{Bb}}$ & $47.9 \pm 2.89^{\mathrm{Ba}}$ & $59.56 \pm 1.52^{\mathrm{Bb}}$ \\
Deltamethrin & $16.56 \pm 1.4^{\mathrm{Aa}}$ & $25.44 \pm 1.9^{\mathrm{Ab}}$ & $17.17 \pm 1.43^{\mathrm{Aa}}$ & $23.72 \pm 3.2^{\mathrm{Ab}}$ \\
Reduction (\%) & 63.10 & 56.00 & 64.15 & 60.17 \\
\hline
\end{tabular}

Within each variety, values labeled with different lowercase letters (a, b, c) are significantly different $(P<0.05)$. Between treatment and control, values labeled with different uppercase letters $(\mathrm{A}, \mathrm{B}, \mathrm{C})$ are significantly different $(P<0.05)$. 


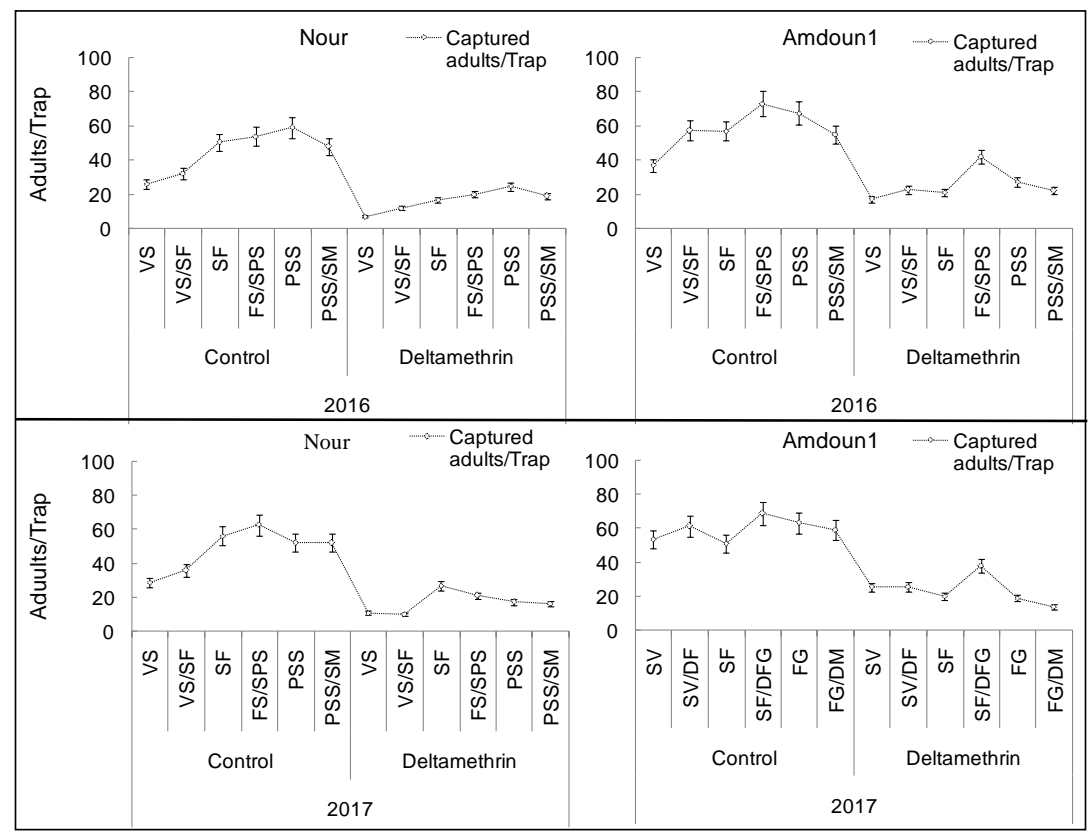

Fig.1. Effect of deltamethrin treatment on captured adults during 2016 and 2017. VS = Vegetative Stage, SF = Start Flowering, SPS = Start Pod Setting, PSS = Pod Setting Stage, SM $=$ Start Maturity.

The effects of varieties, chickpea development stages and treatments, and their interactions (variety $\times$ treatment; variety $\times$ chickpea developmental stage $\times$ treatment) on the number of captured adults/trap were highly significant at $P<$ 0.001. Variance analyzes revealed high significant differences on the number of captured adults among: varieties ( $\mathrm{df}=1$, $\mathrm{F}=986.41, \quad P<0.001)$, chickpea development stages $(\mathrm{df}=5, \mathrm{~F}=349.6, P$ $<0.001)$ and treatments $(\mathrm{df}=1, \mathrm{~F}=$ 9959.54, $P<0.001)$. Interaction term was also highly significant [(Variety $\times$ treatment $(\mathrm{df}=1, \mathrm{~F}=51.6, P<0.001)$, variety $\times$ stage of development $\times$ treatment $(\mathrm{df}=5, \mathrm{~F}=17.73, P<0.001)]$.

\section{Effects of chemical treatments on larvae.}

Statistical analyzes demonstrated high significant differences in live larva numbers among the three chickpea development stages for treated and control plots between winter and spring varieties of each year $(\mathrm{df}=1, \mathrm{~F}=21.48$, $P<0.001)$. However, no significant differences was recorded between the two seasons 2016 and 2017 (df = 1, F = 0.016, $P<0.9$ ). Deltamethrin larvicidal toxicity was assessed according to varieties and chickpea development stages. Results showed that the number of live larvae is lower during vegetative period. Treated samples had fewer live larvae compared to control samples (Table 2). 
Table 2. Effect of deltamethrin treatment on larvae during 2016 and 2017

\begin{tabular}{|c|c|c|c|c|c|c|c|c|c|}
\hline \multirow{3}{*}{ Test } & \multirow{3}{*}{ Stage } & \multicolumn{4}{|c|}{2016} & \multicolumn{4}{|c|}{2017} \\
\hline & & \multicolumn{2}{|c|}{ Nour } & \multicolumn{2}{|c|}{ Amdoun } & \multicolumn{2}{|c|}{ Nour } & \multicolumn{2}{|c|}{ Amdoun } \\
\hline & & $\mathbf{L V}$ & $\mathbf{L D}^{*}$ & $\mathbf{L V}^{*}$ & $\mathbf{L D}^{*}$ & $\mathbf{L V}^{*}$ & $\mathbf{L D}^{*}$ & $\mathbf{L V}^{*}$ & $\mathbf{L D}^{*}$ \\
\hline \multirow{3}{*}{ Control } & VS/SF* & $38.3 \pm 1.4^{\mathrm{a}}$ & $8.67 \pm 0.9^{\mathrm{a}}$ & $43.5 \pm 2.6^{\mathrm{a}}$ & $11.33 \pm 0.2^{\mathrm{a}}$ & $42.3 \pm 1.4^{\mathrm{a}}$ & $11.7 \pm 1.5^{\mathrm{a}}$ & $54.7 \pm 0.9^{\mathrm{a}}$ & $19.3 \pm 0.3^{\mathrm{a}}$ \\
\hline & F/SPS* & $48.3 \pm 0.9^{b}$ & $10.0 \pm 0.6^{\mathrm{b}}$ & $65.7 \pm 6.5^{\mathrm{b}}$ & $18.83 \pm 2.9^{\mathrm{b}}$ & $53.2 \pm 1.5^{\mathrm{ab}}$ & $13.7 \pm 1.5^{\mathrm{ab}}$ & $72.3 \pm 1.4^{\mathrm{b}}$ & $18.3 \pm 0.7^{b}$ \\
\hline & PSS* & $67 \pm 2.3^{\mathrm{c}}$ & $14.0 \pm 0.6^{\mathrm{c}}$ & $75.5 \pm 6.1^{b}$ & $24.5 \pm 1.2^{\mathrm{c}}$ & $59.3 \pm 5.2^{\mathrm{b}}$ & $15.0 \pm 1^{\mathrm{b}}$ & $84.6 \pm 2.9^{c}$ & $24.2 \pm 0.3^{\mathrm{c}}$ \\
\hline \multicolumn{2}{|c|}{ Total } & $51.22 \pm 4.3$ & $10.9 \pm 0.9$ & $61.5 \pm 4.2$ & $18.22 \pm 1.5$ & $51.7 \pm 2.9$ & $13.4 \pm 1.9$ & $66.1 \pm 1.4$ & $19.3 \pm 1.34$ \\
\hline \multirow{3}{*}{$\begin{array}{l}\text { Delta- } \\
\text { methrin }\end{array}$} & $\mathrm{VS} / \mathrm{SF}^{*}$ & $14.83 \pm 1.7^{\mathrm{a}}$ & $12 \pm 0.9^{\mathrm{a}}$ & $20.2 \pm 1.7^{\mathrm{a}}$ & $10.3 \pm 0.8^{\mathrm{a}}$ & $13.67 \pm 1.3^{\mathrm{a}}$ & $17.67 \pm 1.3^{\mathrm{a}}$ & $18 \pm 2.1^{\mathrm{a}}$ & $15.0 \pm 0.6^{\mathrm{a}}$ \\
\hline & F/SPS* & $24.3 \pm 1.4^{\mathrm{b}}$ & $18.0 \pm 0.57^{\mathrm{b}}$ & $37.3 \pm 0.8^{\mathrm{b}}$ & $28.3 \pm 0.8^{\mathrm{b}}$ & $16.00 \pm 2.1^{\mathrm{a}}$ & $23.0 \pm 0.5^{\mathrm{b}}$ & $39.3 \pm 2.08^{b}$ & $22.6 \pm 3.6^{\mathrm{b}}$ \\
\hline & PSS* & $21.3 \pm 0.3^{\mathrm{b}}$ & $12.05 \pm 0.5^{\mathrm{a}}$ & $28.4 \pm 1.6^{\mathrm{b}}$ & $27.0 \pm 1.15^{\mathrm{b}}$ & $11.67 \pm 2.6^{\mathrm{a}}$ & $22.7 \pm 1.15^{\mathrm{b}}$ & $31 \pm 2.02^{\mathrm{b}}$ & $26.3 \pm 2.01^{\mathrm{b}}$ \\
\hline \multicolumn{2}{|c|}{ Total } & $20.16 \pm 0.9$ & $14.01 \pm 0.7$ & $28.6 \pm 1.3$ & $21.86 \pm 0.9$ & $13.8 \pm 1.4$ & $20.89 \pm 0.9$ & $29.4 \pm 2.3$ & $21.3 \pm 2.07$ \\
\hline
\end{tabular}

Within each chickpea development stage, values labeled with different lowercase letters (a, b, c) are significantly different $(P<0.05) ; \mathrm{LV}=$ Live larvae; LD = Dead larvae; *VS/SF = Vegetative Stage/Start Flowering; F/SPS = Flowering/Start Pod Setting; PSS = Pod Setting Stage.

\section{Effects of chemical treatments on parasitoids.}

In total, 3 parasitoids species were identified: one Brachonidae Opius monilicornis, and two Eulophidae Diglyphus isaea and Diaulinopsis arenaria. Statistical analyzes showed high significant differences of the number of parasitoids between treated and control samples for the three parasitoids $[O$. monilicornis $(\mathrm{df}=1, \mathrm{~F}=133.17, P<$ $0.001) ; D$. isaea $(\mathrm{df}=1, \mathrm{~F}=83.42, P<$ $0.001)$ and $D$. arenaria $(\mathrm{df}=1, \mathrm{~F}=24.67$, $P<0.001)]$.
Results showed that $O$. monilicornis was the most abundant species in the untreated samples boxes. The mean number was 16.67individuals in 2016 and 20.56individuals in 2017 for the winter variety (Nour); 19 individuals in 2016 and 45.44 individuals in 2017 for the spring variety (Amdoun). Contrariwise, the mean numbers of the two Eulophidae D. isaea and Diaulinopsis arenaria were low on Amdoun variety, with respectively 8.44 and 8.78 individuals in 2016; 14.89 and 11.78 individuals in 2017 (Fig. 2). 


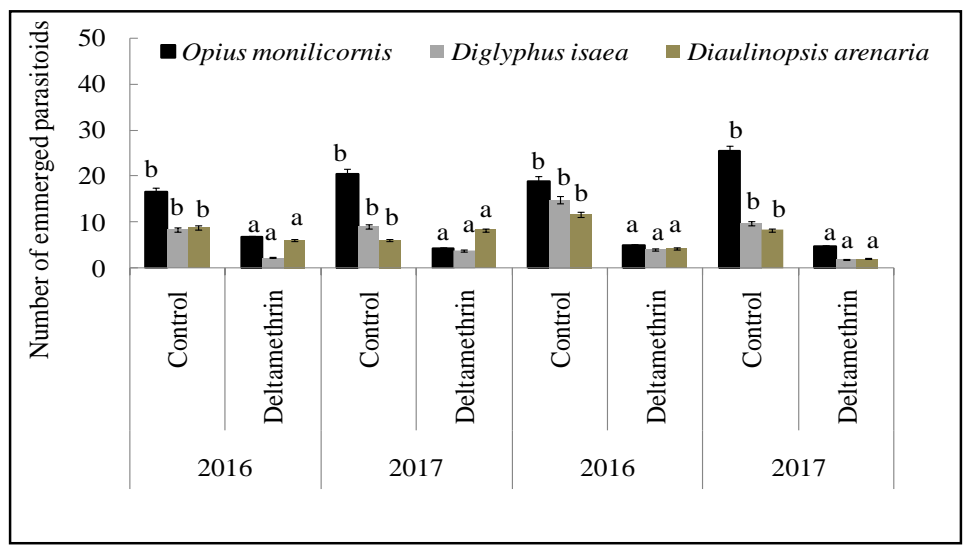

Fig. 2. Effect of deltamethrin treatment on emerged parasitoids during 2016 and 2017.Within each treatment, values labeled with different lowercase letters $(a, b, c)$ are significantly different $(P<0.05)$.

Parasitism rates varied between control and treated samples. Statistical analyzes indicated a high significant difference between control and treated samples for $O$. monilicornis $(\mathrm{df}=1, \mathrm{~F}=$ $38.42, P<0.001), D$. isaea $(\mathrm{df}=1, \mathrm{~F}=$ 5.34, $P<0.02)$ and $D$. arenaria $(\mathrm{df}=1, \mathrm{~F}$ $=14.41, P<0.001)$.
The braconid, $O$. monilicornis was the most abundant species in both control and treated plots with $21.28 \%$ and $8.65 \%$ for Nour variety and $17.63 \%$ and 9.34\% for Amdoun variety during 2016 . The two species $D$. isaea and $D$. areneria have been detected with lower rates of parasitism (Fig. 3).

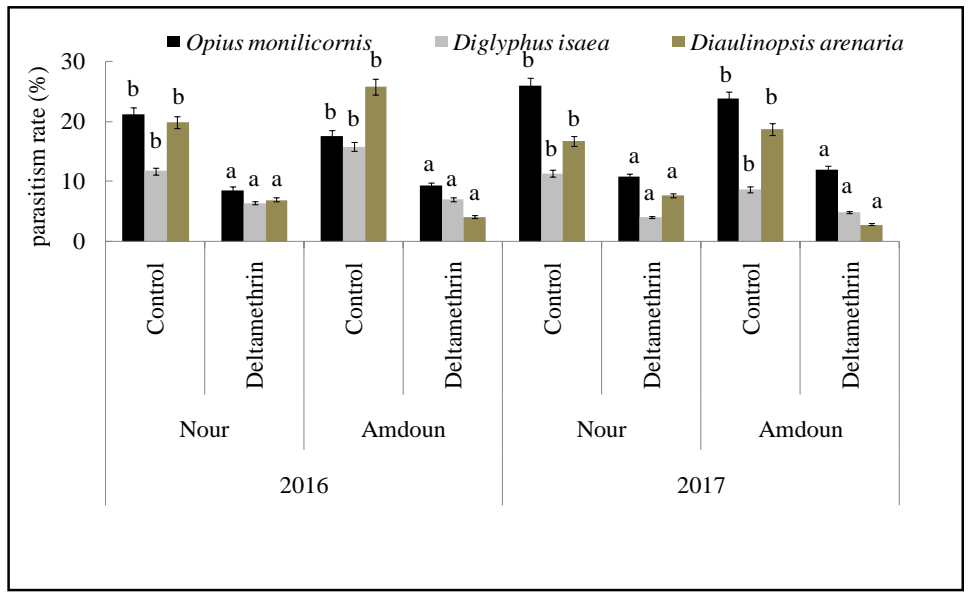

Fig. 3. Effect of deltamethrin treatment on the parasitism rate (\%) during 2016 and 2017.Within each treatment, values labeled with different lowercase letters $(a, b, c)$ are significantly different $(\mathrm{P}<0.05)$; 


\section{DISCUSSION}

In this study, the high numbers of sampled larvae and captured adults were observed during pod setting stage from mid-Aprilto late-May. The evolution of insect incidence revealed that $L$. cicerina adults seems to be more abundant during flowering and pod setting stage as compared to vegetative stage. This may due to climatic parameters and the significant correlation between agro-morphological characteristics and insect pest emergence (Soltani et al. 2020). Moreover, Studies of Lahmar and Zeouienne (1990) released in chickpea fields in Morocco revealed the same results; the infestation caused by $L$. cicerina increased to reach its maximum at late-April.

Chemical treatments reduced the number of adults in chickpea field tests and seem to be efficient against larvae during pod setting stage. As was observed by Banita et al. (1992), chemical treatments were more effective during pod setting stage. Previous studies showed that insecticides have a toxic effect on larvae, pupae and adults of Liriomyza trifolii (Schuster 1994) and other Agromyzidae species (Getzin, 1960). According to our results, deltamethrin treatment had a significant effect for the control of the chickpea leafminer that caused a reduction of $65 \%$ of captured adults. Studies conducted by Çikman et al. (2008) reported that cyromazine treatment induced a reduction of $67.24 \%$ on L cicerina adults.

In the other study, El-Bouhssini et al. (2008) demonstrated that deltamethrin had significant effect on $L$. cicerina population in the two spring and winter tested cultivars by reducing the number of adult parasitoids compared to unsprayed control. These results are in concordance with ours revealing important mortality of treated $L$. cicerina adults and larvae, but deltamethrin reduced significantly parasitoid adult number that was significantly greater for $O$. monilicornis than for $D$. isaea and $D$. arenaria. However, Çikman et al. (2008) revealed that insecticides had effect on different stages of insect pests, while no effect on their natural enemies. Similarly, Sengonca and Liu (2003) Showed that treatment of GCSC-BtA biocide had high efficacy in reducing abundance of insect pests however no effect observed on natural enemies.

The braconid, Opius monilicornis was the most abundant species in the two varieties (Figs. 2 and $3)$. Soltani et al. (2018) revealed the same results with $O$. monilicornis identified as the most emerged parasitoids in the northwest of Tunisia with a parasitism rate of $23.2 \%$.

In conclusion, our results suggest that deltamethrin has the potential to provide control against larval, pupae and adults of $L$. cicerina and infestations could significantly be reduced using chemical treatments. This effectiveness remains considerable when considering particular dates and chickpea developmental stage. In fact, the highest mortality was registered for winter variety comparing to the spring one. Similarly, El-Bouhssini et al. (2008) showed that the winter-sown crop gave the lowest infestation rate as compared to the springsown one. In contrast, insecticides affect the emergence of parasitoids that could be considered as potential biological control agents. Wan et al. (2016) reported that extensive use of chemical insecticides has both positive and negative effects on complex agro-ecosystems. Hence, the use of more selective insecticides, integrated with other IPM components, should be recommended to reduce the negative sideeffects on natural enemies for the control of the chickpea leafminer. In addition, $L$. 
cicerina can be better managed in chickpea winter cropping.

Acknowledgments

Authors are thankful to the Field Crop Regional

Research Center of Beja (CRRGC) for providing fields, laboratory and other facilities. This work was supported by funds from Laboratory of Biotechnology Applied to Agriculture, (INRATLR11INRAT06).

\section{RESUME}

Soltani A., Haouel-Hamdi S., Amri M. et Mediouni-Ben Jemaa J. 2020. Effet de la Deltaméthrine sur la mouche mineuse (Liriomyza cicerina) du pois chiche et ses parasitoïdes.Tunisian Journal of Plant Protection 15 (2): 59-67.

L'objectif de ce travail était d'étudier les effets des traitements chimiques sur les larves et les adultes de la mouche mineuse du pois chiche (Liriomyza cicerina) et ses parasitoïdes. L'étude a été effectuée selon le dispositif split-plot, pendant les compagnes agricoles 2016 et 2017 au nord-ouest de la Tunisie. Le traitement avec la deltaméthrine a été appliqué sur les variétés d'hiver et de printemps (Nour et Amdoun, respectivement) lorsque la densité du ravageur atteint un niveau de 2 à 3 larves/feuille dans $50 \%$ des plantes du champ. Le nombre de parasitoïdes et d'adultes du ravageur émergés a été enregistré et les taux de parasitisme ont été étudiés après les traitements à la deltaméthrine. Les résultats ont révélé que le nombre d'adultes capturés a été réduit dans les parcelles traitées par rapport aux parcelles témoins. Les pourcentages de réduction respectifs ont atteint $64,15 \%$ et $60,17 \%$ pour les variétés Nour et Amdoun en 2017. De plus, les taux de parasitisme les plus et les moins élevés ont été enregistrés respectivement pour Opius monilicornis $26.09 \%$ sur les échantillons non-traités et pour Diaulinopsis arenaria 2,88\% sur les échantillons traités de la variété Nour. Pour toutes les expérimentations, la mortalité des larves et des adultes de L. cicerina et ses parasitoïdes était plus élevée pour les cultures pois chiche de printemps. Ainsi, l'utilisation d'insecticides plus sélectifs doit être recommandée pour réduire les effets négatifs secondaires sur les ennemis naturels de la mouche mineuse du pois chiche.

Mots-clés: Deltaméthrine, Liriomyza cicerina, nord-ouest de la Tunisie, parasitoïdes, pois chiche

ملخصني، عبير وسمية حوال-حمدي ومعز عمري وجودة مديوني-بن جماعة. 2020. تأثير دلتامثرين على حافرة أوراق

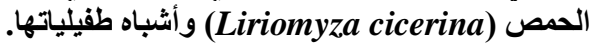

Tunisian Journal of Plant Protection 15 (2): 59-67.

الهدف من هذا العمل هو در اسة تأثير المعاملات الكيميائية بالمبيد دلتامثرين على الاطو ار اليرقية و الحشر ات البالغة لحافرة

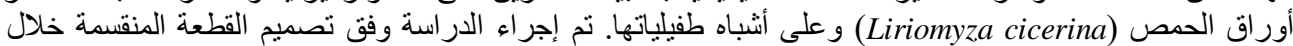

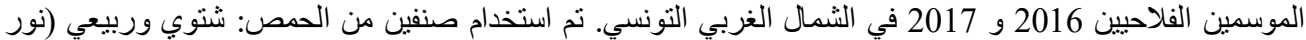

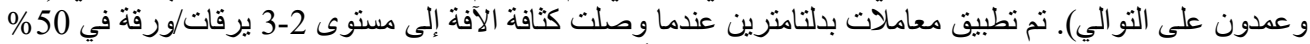

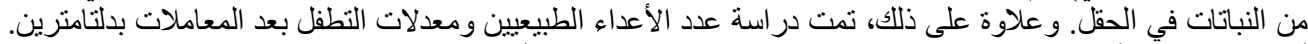

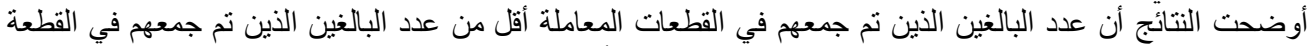

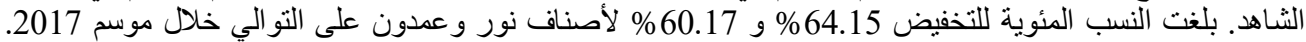

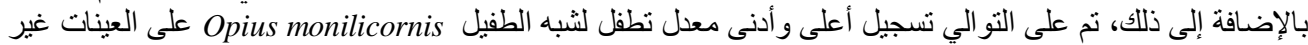

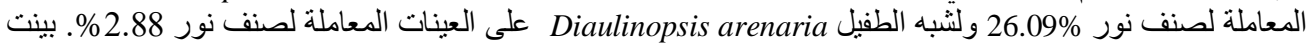

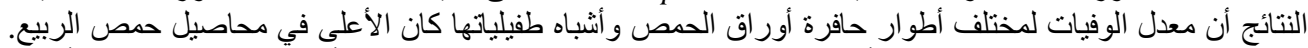

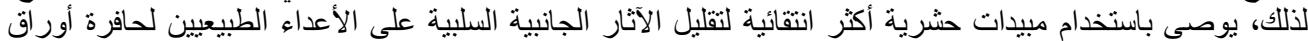

كلمات مفتاحية: أشباه الطفيليات، الثمال الغربي التونسي، حمص، دلتامثرين، Liriomyza cicerina 


\section{LITERATURE CITED}

Banita, E., Mateias M., and Luca,E. 1992. Liriomyza Cicerina Rond. (Diptera-Agromyzidae) - A Major Pest of Chickpea Crops. Probleme De Proteçtia Plantelor 20: 25-37.

Çikman, E., Kaplan, M., and Cokun, Y. 2008. The Effects of Bacillus thuringiensis on larval serpentine leaf miners Liriomyza cicerina (Rondani, 1875)(Dipetera: Agromyzidae) in Chickpea. Journal of Applied Sciences Research 4: 1191-1198.

Crkman, E., and Uygun, N. 2003. The Determination of Leafminers (Diptera: Agromyzidae) and Their Parasitoids In Cultivated and Non-Cultivated Areas In Şanlıurfa Province, Southern Turkey. Türkiye Entomoloji Dergisi 27: 305-318.

Del Cañizo, J. 1934. Dos Agromícidos Perjudiciales Al Garbanzo. Boletin Patologia Vegetal Entomologia Agricola Spain 7: 91-103 .

El-Serwy, S. 2003. Studies on the Leafminers; Liriomyza Cicerina (Rondani) And Liriomyzabryoniae (Kaltenbach)(Diptera: Agromyzidae) and Their Parasitoids in Faba Bean in Egypt. Egyptian Journal of Agricultural Research 81: 1581-1593.

El Bouhssini, M., Mardini, K.,Malhotra, R., Joubi, A., and Kagka, N. 2008. Effects of planting date, varieties and insecticides on chickpea leaf miner (Liriomyza Cicerina Rond) Infestation and the parasitoid Opius monilicornis F. Crop Protection 27: 915-919.

Getzin, L. 1960. Selective Insecticides for Vegetable Leaf-Miner Control and Parasite Survival. Journal of Economical Entomology 53: 872875.

Lahmar, M., and Zeouienne, M. 1990. Donnèes BioEcologiques et Importance dDes Dègats de la Mineuse du Pois-Chiche (Liriomyza Cicerina, Rond.) Au Maroc. Al Awamia 26: 108-118.

Naresh J., and Malik, V. 1986. Observations on the insect pests of chickpea (Cicer arietinum 1.) in haryana. Bulletin of Entomology 27: 75-77.

Reed, W., Cardona, C., Sithanantham, S., and Lateef, S. 1987. Chickpea Insect Pest and Their Control. Pages 283-318. In: The Chickpea. Ed. CAB International, Wallingford, Oxon, UK

Russell, D.A. 1987. A simple method for improving estimates of percentage parasitism by insect parasitoids from field sampling of hosts. New Zealand Entomology 10: 38-40.

Schuster, D. 1994. Life stage specific toxicity of insecticides to parasitoids of Liriomyza Trifolii (Burgess) (Diptera: Agromyzidae). International Journal of Pest Management 40: 191-194.

Soltani, A., Beyareslan, A.,Gençer, L.,Hamdi, S.H.,Bousselmi, A., Amri, M., and Jemâa, J.M.B. 2018. Parasitoids of chickpea leafminer Liriomyza cicerina (Diptera: Agromyzidae) and their parasitism rate on chickpea fields in north tunisia. Journal of Asia Pacific of Entomology 21: 1215-1221.

Soltani, A., Zouali, Y., Haoual-Hamdi, S., Saadouni, D., Amri, M., Carapelli, A., and Mediouni Ben-Jemâa, J. 2020. Relationship between secondary metabolites and infestations caused by chickpea leafminer Liriomyza cicerina (Diptera: Agromyzidae). International Journal of Tropical Insect Science 1: 1-9.

Spencer, K.A. 1976. The Agromyzidae (Diptera) of fennoscandia and denmark. Fauna Entomologica Scandinavica 5: 1-606.

Toker, C., Erler, F., Ceylan, F.O., and Canci, H., 2010. Severity of leaf miner [Liriomyza cicerina (Rondani, 1875) (Diptera: Agromyzidae)] damage in relation to leaf type in chickpea. Turkish Journal of Entomology 34: 211-225.

Wan, F-H., and Yang, N-W.2016. Invasion and management of agricultural alien insects in china.Annual Review of Entomology 61: 7798.

Weigand, S. 1990. Development of an integrated pest management system in food legumes in the icarda region. Page 53-76. In: Proceedings of Integrated Pest Management in Tropical and Subtropical Cropping Systems. 1990, ICARDA, Aleppo, Syria.

Weigand, S., Lateef, S., El-Din, N.E.D.S., Mahmoud, S., Ahmed, K., and Ali, K. 1994. Integrated Control of Insect Pests of Cool Season Food Legumes. Pages 679-694. In: Expanding the production and use of cool season food legumes, Shyam Yadav, D. McNeil, R. Redden, S. Patil, Eds. Springer Nature, Switzerland. 
